\title{
Postfire Restoration of Soil Hydrology and Wildland Vegetation Using Surfactant Seed Coating Technology
}

\author{
Matthew D. Madsen, ${ }^{1}$ Stanley J. Kostka, ${ }^{2}$ Aaron L. Inouye, ${ }^{3}$ and Daniel L. Zvirzdin ${ }^{4}$ \\ Authors are ${ }^{1}$ Ecologist, USDA-ARS, Burns, OR 97720, USA; ${ }^{2}$ Director of Technology and Business Development, Aquatrols Corporation of America, \\ Paulsboro, NJ 08066, USA; and ${ }^{3}$ Undergraduate Student and ${ }^{4}$ Graduate Student, Department of Plant and Wildlife Sciences, Brigham Young University, \\ Provo, UT 84642, USA.
}

\begin{abstract}
In semiarid environments, soil water repellency can contribute to reseeding failure by reducing soil moisture availability. Nonionic soil surfactants (wetting agents) have been shown to be effective in enhancing infiltration and improving root-zone water reserves in waterrepellent soils. However, the application of soil surfactants in wildland ecosystems can be logistically and economically prohibitive. In this study, we evaluated a potential solution for applying soil surfactants using seed coating technology. Through this technology, the seed is used as a carrier for the soil surfactant. After planting, water transfers the surfactant from the seed into the soil where it ameliorates the water repellency within the seed's microsite. The objectives of this research were 1) to establish the efficacy of a surfactant seed coating (SSC) in ameliorating soil water repellency, and 2) to determine the influence of SSC on seedling emergence and plant survival. To accomplish the first objective, detailed soil column experiments were conducted in the laboratory on water-repellent soil obtained from a burned pinyon-juniper (Pinus-Juniperus spp.) woodland. The second objective was met through greenhouse testing of SSC applied to crested wheatgrass and bluebunch wheatgrass seed, using the same soil as used in the first objective. Results indicate that SSC increased soil water infiltration, percolation, and retention. This technology had no influence on seedling emergence for crested wheatgrass, but SSC improved bluebunch wheatgrass (Pseudoroegneria spicata [Pursh] Á. Löve) emergence threefold. Plant survival was dramatically improved by the SSC. Only $0.75 \%$ of the seedlings that grew from noncoated seed survived to the end of the study, whereas $37 \%$ of the plants survived in the SSC treatment. Overall, these results indicate that it may be plausible for SSC to improve postfire restoration efforts by restoring soil hydrologic function and increasing seedling emergence and early seedling development.
\end{abstract}

\section{Resumen}

En las zonas semiáridas, la repelencia del agua del suelo puede contribuir a las fallas de las resiembras reduciendo la disponibilidad de la humedad del suelo. Los surfactantes no iónicos del suelo (agentes de adherencia) han demostrado ser eficaces en ayudar la infiltración y mejorar las reservas de agua de la zona de la raíz en suelos impermeables. Sin embargo, el uso de surfactantes en suelos de ecosistemas de pastizales puede ser logísticamente y económicamente prohibitivo. En este estudio evaluamos una solución viable para aplicar los surfactantes del suelo usando tecnología para cubrir la semilla. Con esta tecnología la semilla se utiliza como portador para el surfactante del suelo. Después de ser plantada, el agua transfiere el surfactante de la semilla en el suelo donde mejora la repelencia del agua dentro del micro-sitio de la semilla. Los objetivos de esta investigación fueron 1) establecer la eficiencia de una cubierta en la semilla del surfactante (SSC) en el mejoramiento de repelencia del agua del suelo, y 2) determinar la influencia de SSC en la aparición de las plántulas y la sobrevivencia de las plantas. Para llevar a cabo el primer objetivo, se realizaron experimentos detallados en columnas de suelos en el laboratorio utilizando suelo impermeable obtenido de una área quemada de piñón -junípero. El segundo objetivo fue resuelto en pruebas de SSC conducidas en el invernadero aplicadas a semillas de triguillo crestado y bluebunch wheatgrass usando el mismo suelo del objetivo 1. Los resultados indican que SSC aumentó la infiltración, la percolación, y la retención del agua del suelo. Esta tecnología no tiene ningún efecto en la aparición de las plántulas de triguillo crestado pero SSC mejoró triple la aparición del bluebunch wheatgrass. La sobrevivencia de las plantas fue mejorada dramáticamente por el SSC. Solamente el $0.75 \%$ de las plántulas que crecieron de la semilla no-revestida sobrevivieron al final del estudio, mientras que el $37 \%$ de las plantas sobrevivieron en el tratamiento de SSC. En general, estos resultados indican que puede posible que SSC mejore los esfuerzos de la restauración después de las quemas restaurando la función hidrológica del suelo y aumentando la aparición de la plántula, así como desarrollo más rápido de las mismas plántulas.

Key Words: pinyon-juniper, reseeding, revegetation, water-repellency, wetting agent, wildfire

\section{INTRODUCTION}

Funding for this research was provided by the Utah Department of Food "War on cheatgrass grant," USDA-National Institute of Food and Agriculture's Rangeland Research Program, and the USDA-ARS. Mention of a proprietary product does not constitute a guarantee or warranty of the product by USDA or the authors and does not imply its approval to the exclusion of the other products that also may be suitable. USDA is an equal opportunity provider and employer.

Correspondence: Dr. Matthew D. Madsen, USDA-ARS, Eastern Oregon Agricultural Research Center, Burns, OR 97720, USA. Email: matthew.madsen@oregonstate.edu

Manuscript received 20 May 2011; manuscript accepted 11 February 2012
Land managers commonly seed wildland areas that have been affected by catastrophic wildfires to promote recovery of desired vegetation and mitigate risks from runoff, soil erosion, air pollution, and weed infestation (Richards et al. 1998; Bureau of Land Management 1999; Epanchin-Niell et al. 2009; Hardegree et al. 2011). Unfortunately, current postdisturbance seeding practices often experience poor seedling establishment, leaving sites susceptible to ecological degradation (Lysne and Pellant 2004; James and Svejcar 2010). This major shortcoming 


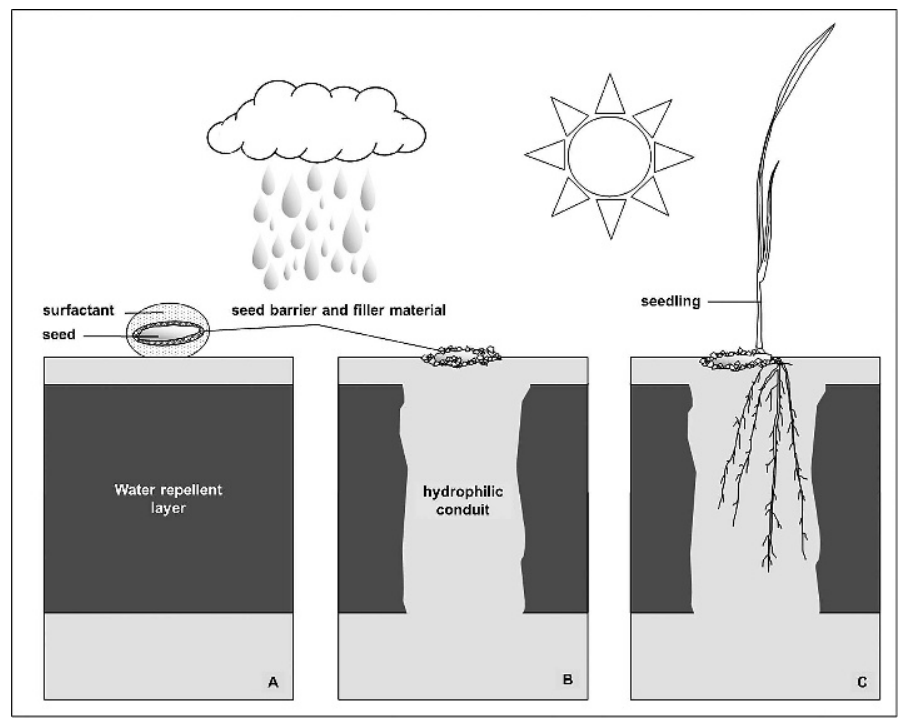

Figure 1. A, Schematic diagram of a seed coated first with a seed barrier followed by soil surfactant. B, Precipitation releases the surfactant into the soil overcoming the water-repellent layer, resulting in a hydrophilic conduit within the microsite of the seed. C, Enhanced soil moisture promotes seed germination and seedling survival.

emphasizes the need to develop seeding methods that overcome the factors impairing reseeding success (James et al. 2011).

Soil water repellency (or hydrophobicity) is a condition frequently found following fire that can impair reseeding success. This soil condition is produced or intensified during fire as hydrophobic molecules in the litter volatilize and then condense around soil particles at or below the soil surface (DeBano et al. 1976; Doerr et al. 2009). The resultant soil composition decreases site stability by impeding infiltration and promoting runoff and soil erosion (DeBano 1981; Doerr et al. 2009). Recovery is also impaired because water repellency decreases the soil's ability to absorb and retain moisture (Doerr et al. 2000; Ravi et al. 2010), which prolongs the effects of fire by impairing seed germination and decreasing seedling survival (Osborn et al. 1967; Adams et al. 1970; DeBano et al. 1970; Savage 1974; Madsen et al. 2012).

Restoration approaches that ameliorate water repellency could improve the success of native plant materials in postfire reseeding efforts (Madsen et al. 2012). Small-plot studies conducted in the 1960s and 1970s showed that soil surfactants (or wetting agents) can mitigate the effects of postfire water repellency by reducing debris movement, surface runoff, and rill erosion and by improving vegetative cover (Pelishek et al. 1962; Osborn et al. 1967; Krammes and Osborn 1969; Valoras et al. 1974). Since that time, soil surfactants have been primarily and extensively used in landscape management (Kostka 2000; Karnok and Tucker 2001; Soldat et al. 2010; Oostindie et al. 2011), horticulture, and agriculture (Kelling et al. 2003). As a result, research has been implemented to improve the effectiveness of these chemicals in treating soil water repellency (Kostka and Bially 2005; Kostka et al. 2008; Kostka 2009). Despite these advancements, the broadcast application of this soil amendment may not be practical in wildland systems because of the low economic value of the land and the extensive areas requiring treatment.
A recent US patent application (201028371) described a method to coat individual seeds with soil surfactants (Madsen et al. 2010). It is assumed that this method will enable the economic dispersal of surfactant and seed together (Fig. 1A) and increase soil water availability for seeds and seedlings in water-repellent soil (Fig. 1B). The latter is achieved through 1) enhanced infiltration and moisture retention within the area treated by the surfactant; 2) movement of moisture toward the seed because of the surrounding water-repellent soil directing precipitation to the higher infiltration areas created by the surfactant; 3) reconnecting the upper soil surface with the underlying soil matrix, which allows the transfer of moisture by capillarity toward the seedling as the soil surface dries; and 4) opening up of a hydrophilic channel that allows seedlings roots the ability to grow and access underlying soil moisture reserves (Fig. 1C).

This study was conducted to evaluate the methods developed by Madsen et al. (2010) in the laboratory and greenhouse. The first objective was to determine whether surfactant seed coating (SSC) was effective in ameliorating water-repellent soil within the seed's microsite. We hypothesized that SSC would enhance infiltration and moisture retention in the soil proximal to the treated seed. The second objective was to determine how coating seeds with surfactant would influence seedling emergence and survival in water-repellent soil. We hypothesized the SSC would increase seedling emergence, survival, and plant growth in comparison to uncoated seeds.

\section{MATERIALS AND METHODS}

\section{Experiment 1: Effectiveness of Surfactant-Coated Seeds in Ameliorating Soil-Water Repellency}

Experiment 1 was designed to assess the effectiveness of SSC in ameliorating soil-water repellency. Research was performed by dripping water over a single seed placed in a soil column that was filled with water-repellent soil. The experiment was performed on noncoated seed (control) and on seed with a SSC treatment, with 7 replicates per treatment.

We used the native species bluebunch wheatgrass (Pseudoroegneria spicata [Pursh] Á. Löve) as the model species in this evaluation. Bluebunch wheatgrass was chosen based on its common occurrence in reseeding projects within the Intermountain Region of the western United States. Seeds were coated with the soil surfactant ACA-2045 (Aquatrols Corporation of America, Paulsboro, NJ), which is a nonionic soil surfactant composed of a blend of alkyl polyglycoside and ethylene oxide/ propylene oxide block copolymers (Kostka and Bially 2005). The chemistry of this surfactant has been documented in multiple studies to enhance infiltration and improve root-zone water reserves in water-repellent soils (Kostka and Bially 2005; Mitra et al. 2006; Moore et al. 2010; Madsen et al. 2012).

Seeds were coated using a RP14DB rotostat seed coater by BraceWorks Automation and Electric (Lloydminster, SK, Canada). To prevent the surfactant from delaying germination, seeds were first coated with a barrier coating as described by Madsen et al. (2010). Immediately after the barrier treatment was applied, seeds were coated with surfactant at $127 \%$ weight of product to weight of seed (w/w; Fig. 1A). To aid in seed buildup and to prevent seeds from sticking together, powder 
filler was applied with the surfactant at $66 \%$ w/w. Filler was composed of a mixture of $65 \%$ crushed limestone (Clayton's Calcium, Inc, Meridian, ID) and 35\% Oil Dri (Oil-Dri Corporation of America, Alpharetta, GA) by weight. Limestone was ground to less than 200 mesh, with the bulk smaller than 300 mesh. This high-density material was chosen to improve the ballistic properties of aerially planted seeds. Oil Dri is a montmorillonite, clay-based product that has high absorbent properties; this material was used to minimize the amount of filler needed during the coating process.

Water-repellent soil was collected from the 2009 White Rocks wildfire beneath burned Utah juniper trees (Juniperus osteosperma [Torr.] Little). The White Rocks wildfire occurred $10.25 \mathrm{~km} \mathrm{NW}$ of Dugway, Utah (lat $40^{\circ} 17^{\prime} 0.07^{\prime \prime} \mathrm{N}$, long $\left.112^{\circ} 49^{\prime} 55^{\prime \prime} \mathrm{W}\right)$. The soil at this location was classified as Medburn fine sandy loam, coarse-loamy, mixed, superactive, calcareous, mesic Xeric Torriorthents. We measured the severity of the water-repellent soil with the water drop penetration time (WDPT) test by placing 10 replicate drops of water on the soil surface and recording the time for each drop to penetrate into the soil (Ritsema et al. 2008).

Water-repellent soil was lightly packed to a depth of $6 \mathrm{~cm}$, in a 2.8 -cm-diameter column that had been fitted with a fine-mesh screen bottom and an outflow tube at the soil surface (Fig. S1, available online at http://dx.doi.org/10.2111/REM-D-1100083.s1). For each soil core, we applied $38 \mathrm{~mL}$ of water at a rate of $7.0 \mathrm{~cm} \cdot \mathrm{h}^{-1}$, using a constant-drip apparatus (Fig. S1). This volume was equal to the field capacity of the core plus an additional $35 \%$ to increase the probability of percolation through the bottom of the soil core. Field capacity of the soil was determined through the "container capacity" method (Cassel and Nielsen 1986), on five replicate soil cores.

Water was delivered to the soil column at a constant rate through the use of a Marriott bottle. The Marriott device delivered water through a $3.2-\mathrm{mm}$ vinyl hose attached to a 10G, 25.4-mm hypodermic needle suspended $20 \mathrm{~mm}$ above the soil surface (Fig. S1).

Following water application, runoff and percolation were determined by measuring the total amount of water within beakers placed below the runoff tube and the bottom of each soil core, respectively. Percolation time was determined by recording the time from the start of the water application to when water started to drip from the bottom of the column. Soil water content retention was measured gravimetrically by subtracting the weight of the soil column at the start of the experiment from the weight of the soil column after water stopped dripping.

\section{Experiment 2: Influence of SSC on Seedling Emergence and Survival in Postfire Water-Repellent Soil}

Experiment 2 was conducted to determine how coating seeds with surfactant would influence seedling emergence and survival in water-repellent soil. Research was conducted from 12 August 2010 to 14 October 2010 in a greenhouse at the Eastern Oregon Agricultural Research Center in Burns, Oregon. In that facility, temperature was not regulated, and no supplemental lighting was used. The greenhouse was covered with a $4 \%$ shade cloth, light averaged $1333 \mathrm{mmol} \cdot \mathrm{m}^{-2} \cdot \mathrm{s}$ between 1000 and 1600 hours. The photoperiod ranged from $14 \mathrm{~h} 8 \mathrm{~min}$ (at the start of the study) to $11 \mathrm{~h} 4 \mathrm{~min}$ (at the conclusion of the study). Air temperature averaged $14.6^{\circ} \mathrm{C}$.

Soil for this study was obtained from the same location as that used in experiment 1 . In addition to obtaining soil from the water-repellent layer, we also separately extracted soil from the surface hydrophilic layer (or ash layer) and the subsurface hydrophilic layer found below the water-repellent layer. These three soil layers were then placed into square $14 \times 14 \mathrm{~cm}$ pots in the same order as found in the field. Surface hydrophilic and water-repellent soils were layered $10 \mathrm{~mm}$ and $46 \mathrm{~mm}$ thick, respectively; thicknesses were chosen to replicate those found in the field by Madsen et al. (2011). The subsurface hydrophilic soil was placed in the pot at a depth of $75 \mathrm{~mm}$. To accentuate the influence of the water-repellent soil and better represent wildland systems with sloping terrain, pots were placed on a $10^{\circ}$ slope and a v-notch $(2 \mathrm{~cm}$ tall $\times 2 \mathrm{~cm}$ wide at the top $)$ was cut in the pot at the soil surface to allow for drainage.

A completely randomized design with two species, two treatments, and 10 replications was implemented, for a total of 40 pots in the study $(2$ species $\times 2$ treatments $\times 10$ replications $=40$ pots). Species included bluebunch wheatgrass and the introduced species crested wheatgrass (Agropyron cristatum [L.] Gaertn.). The same seed treatments used in experiment 1 (control and SSC) were also evaluated here. Within each pot, the pure, live equivalent of 10 seeds was planted at a depth of $3.0 \mathrm{~mm}$ below the soil surface.

At the time of seeding, pots were watered daily with approximately $20 \mathrm{~mL}$, at a rate of $9 \mathrm{~cm} \cdot \mathrm{h}^{-1}$ to encourage seed germination. After $2 \mathrm{wk}$, pots were watered weekly with approximately $110 \%$ of the average weekly amount of precipitation received in the spring for the area the soil was collected (depth of water added was equal to $6.38 \mathrm{~mm}$, which was equal to $125.0 \mathrm{~mL}$ per pot; PRISM Climate Group 2011).

During the period seedlings were emerging from the soil $(0-$ $20 \mathrm{~d}$ after seeding), plant density was counted every $3-4 \mathrm{~d}$ by taking a census of all live seedlings within each pot. After day 20 , plant density was counted weekly. At the conclusion of the study ( $63 \mathrm{~d}$ after seeding), plants were harvested. Aboveground biomass was weighed after it had been dried at $65^{\circ} \mathrm{C}$ for $72 \mathrm{~h}$.

\section{Statistical Analysis}

The data were analyzed in SAS (Version 9.1; SAS Institute, Cary, NC). In experiment 1 , paired two-sample $t$ tests were used to determine differences in runoff, percolation time, amount of percolation, and gravimetric water content between the two treatments. In experiment 2 , seedling density data were analyzed using repeated-measures mixed-model analysis with an autoregressive order 1 covariance. In the model, seed treatments were considered fixed factors, and sampling period was designated as a repeated measure. A general linear model analysis of variance (ANOVA) was used to determine differences in live seedlings at peak plant density counts (approximately 14-17 d after seeding), final plant density (those seedlings alive at the conclusion of the study), seedling survival (percentage of difference between peak and final plant density counts), and final aboveground biomass. Mean values were separated using the Tukey-Kramer honestly significant difference multiple-comparison method. To account for zero 


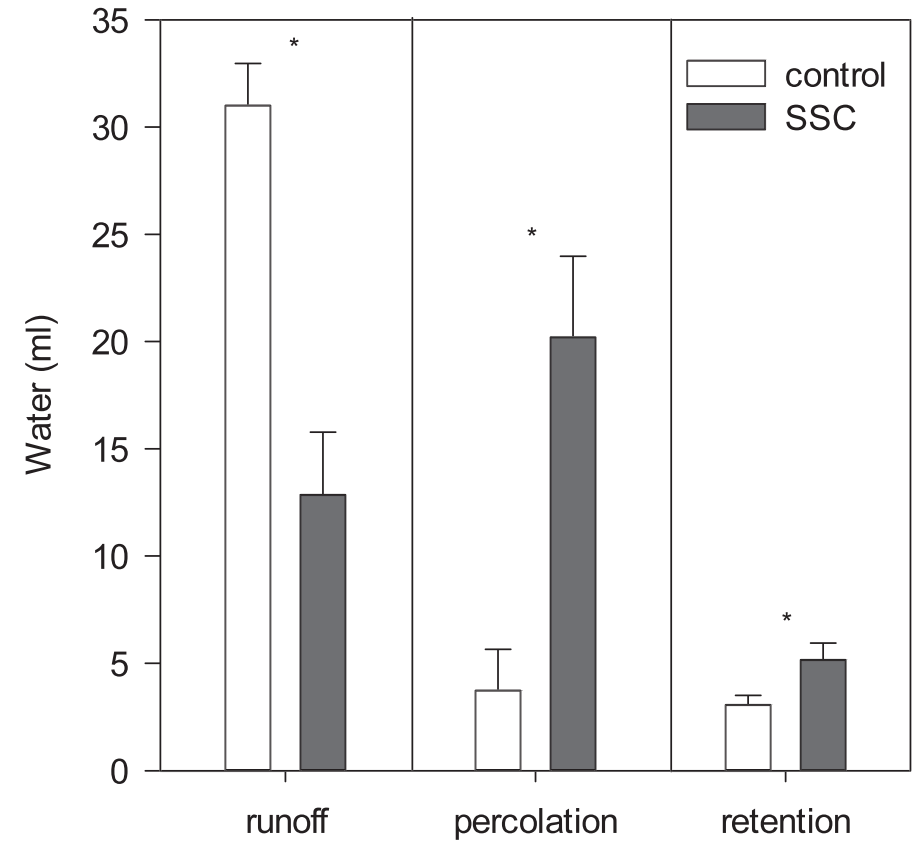

Figure 2. Mean \pm SE $(n=7)$ runoff, percolation, and soil-water retention in soil cores after applying $38 \mathrm{~mL}$ of water to soil cores that were filled with water-repellent soil that had either a noncoated seed (control) or a seed with a surfactant seed coating (SSC). Asterisks indicate significant differences between treatments, for each measurement type $(P<0.05)$.

values a constant (1) was added to the measured values, and all data sets, with the exception of peak density, were square-root transformed before analysis. For all comparisons, a significance level of $P<0.05$ was used. In the text and figures, means are reported with their associated standard errors.

\section{RESULTS}

\section{Experiment 1}

The soil exhibited an average WDPT of $3168 \pm 48 \mathrm{~s}$, which, according to categories established by Doerr et al. (2000), would be considered a "class 3 ," severely water-repellent soil. Soil column test results indicate that SSC improved infiltration and soil water content (Fig. 2). SSC's decreased runoff by $59 \%$ as compared with the control $(P<0.001$; Fig. 2$)$. The amount of percolation through the soil columns was more than three times greater for the SSC treatment $(P<0.001$; Fig. 2$)$. In addition, percolation only occurred in $57 \%$ of the control soil columns, whereas all of the columns percolated for the SSC treatment. Comparison of the control soil columns where percolation did occur with the SSC demonstrated that percolation time was 2.2 times higher in the SSC treatment $(P<0.001$, data not shown). Measurements of gravimetric soil water content showed that SSC increased the amount of water retained in the soil by $68 \%$ in comparison to the control $(P=0.039$; Fig. 2$)$.

\section{Experiment 2}

Seedling density varied over the course of the study by species, treatment, and species by treatment (Table 1). Seedling density peaked $14 \mathrm{~d}$ and $17 \mathrm{~d}$ after seeding for the control and coated seeds, respectively. At peak density, the number of surviving plants was significantly influenced by species, treatment, and species by treatment interactions (Table 1). Peak densities for the crested wheatgrass treatments and bluebunch wheatgrass SSC treatment were similar (Fig. 3). Peak density of bluebunch wheatgrass SSC was three times higher than the bluebunch wheatgrass control (Fig. 3).

Following the termination of the daily watering regime, plants in the control treatment for both species rapidly desiccated (Fig. 3). At the conclusion of the study, density in the crested wheatgrass control treatment had declined by $98.5 \%$ from peak density counts; bluebunch wheatgrass control treatment experienced $100 \%$ mortality. The SSC treatment improved plant survival similarly between species, with $35.7 \%$ and $38.4 \%$ of crested wheatgrass and bluebunch wheatgrass seedlings, respectively, from peak density counts surviving to the end of the study, respectively.

Differences in aboveground plant biomass between treatments were also distinct (Table 1). Biomass from crested wheatgrass SSC was $1554.0 \%$ greater than the control, with the control and SSC treatment producing $0.2 \mathrm{~g} \cdot \mathrm{m}^{-2}$ and $3.6 \mathrm{~g} \cdot \mathrm{m}^{-2}$, respectively. Bluebunch wheatgrass SSC produced $3.1 \mathrm{~g} \cdot \mathrm{m}^{-2}$ of aboveground biomass, which was statistically similar to crested wheatgrass SSC treatment. A percentage difference between the control and SSC treatment for bluebunch wheatgrass could not be computed because of the lack of surviving seedlings in the control treatment.

Table 1. Analysis results from repeated-measures mixed-model analysis for the effect of surfactant seed coating treatments on plant density during the course of the study and general linear-model ANOVA results from peak plant density (approximately 14-17 d after seeding), final plant density, seedling survival, and aboveground biomass.

\begin{tabular}{|c|c|c|c|c|c|c|c|c|c|c|}
\hline \multirow[b]{2}{*}{ Source } & \multicolumn{2}{|c|}{ Density } & \multicolumn{2}{|c|}{ Peak density } & \multicolumn{2}{|c|}{ Final density } & \multicolumn{2}{|c|}{ Seedling survival } & \multicolumn{2}{|c|}{ Biomass } \\
\hline & $\mathrm{F}$ & $\operatorname{Pr}>\mathrm{F}$ & $\mathrm{F}$ & $\mathrm{Pr}>\mathrm{F}$ & $\mathrm{F}$ & $\operatorname{Pr}>\mathrm{F}$ & $\mathrm{F}$ & $\operatorname{Pr}>\mathrm{F}$ & $\mathrm{F}$ & $\operatorname{Pr}>\mathrm{F}$ \\
\hline Species & 124.3 & 0.057 & 18.5 & $<0.001$ & 0.9 & 0.357 & 0.2 & 0.701 & 0.4 & 0.541 \\
\hline Treatment & 248.1 & 0.040 & 7.1 & 0.012 & 48.6 & $<0.001$ & 47.5 & $<0.001$ & 23.3 & $<0.001$ \\
\hline Time & 57.9 & $<0.001$ & - & - & - & - & - & - & - & - \\
\hline Species $\times$ treatment & 21.9 & 0.134 & 11.4 & 0.002 & 0.2 & 0.675 & 0.1 & 0.927 & 0.1 & 0.795 \\
\hline Species $\times$ time & 10.3 & $<0.001$ & - & - & - & - & - & - & - & - \\
\hline Treatment $\times$ time & 9.9 & $<0.001$ & - & - & - & - & - & - & - & - \\
\hline Species $\times$ treatment $\times$ time & 3.2 & 0.001 & - & - & - & - & - & - & - & - \\
\hline
\end{tabular}




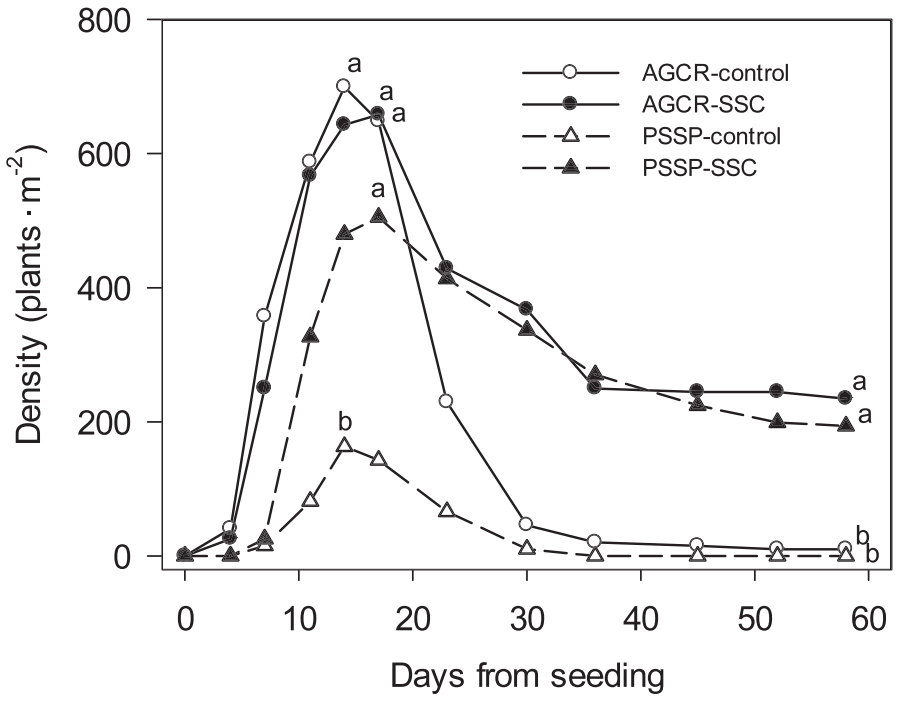

Figure 3. Mean $(n=10)$ plant density during the course of the study from noncoated seeds (control) and seeds with a surfactant seed coating (SSC), for the species crested wheatgrass (AGCR) and bluebunch wheatgrass (PSSP). Analysis was performed at peak density (approximately 14-17 $\mathrm{d}$ after seeding) and at final density. The control treatment for both species was not included in the analysis for final density because of the lack of surviving seedlings. Different lowercase letters indicate significant differences among treatments at each analysis period $(P<0.05)$

\section{DISCUSSION}

The results of this study are consistent with previous studies that showed that soil surfactants can improve ecohydrologic properties essential for plant growth and establishment on postfire water-repellent soil (e.g., Osborn et al. 1967; Krammes and Osborn 1969; Debano and Conrad 1974; Madsen et al. 2012). This is the first study, to our knowledge, to demonstrate that soil surfactants can be applied through the use of seedcoating technology to enhance seedling emergence and survival by restoring the hydrologic function within the seed microsite.

The ability of SSC technology to improve infiltration may be useful for improving soil stabilization efforts after a wildfire. Even when reseeding practices are successful, plant cover is not always high enough to stabilize soils during the first and second years following a fire (Robichaud et al. 2000; Robichaud et al. 2006; Peppin et al. 2010). A case study by MacDonald and Larsen (2009) in midelevation coniferous forests indicated that the most effective postfire rehabilitation treatments are those that immediately provide surface cover. However, those methods are costly; for example, straw mulching has been shown to range between US $\$ 1000$ and $\$ 3000 \mathrm{ha}^{-1}$ (MacDonald and Larsen 2009). Consequently, the application of such strategies can be limited at large scales. Aerial seeding with a fixed-wing aircraft or helicopter can be performed over extensive areas and difficult to access sites at a cost of approximately US $\$ 45 \mathrm{ha}^{-1}$ (MacDonald and Larsen 2009). SSC may more than double those aerial reseeding costs; however, they could prove to be more cost effective in improving stand establishment and reducing soil erosion in comparison to typical aerial seeding or other more laborand material-intensive postfire treatments (e.g., mulching, hydroseeding, or alternative chemical applications, such as polyacrylamide).

Species response to SSC technology was variable at the seedling-emergence phase. The SSC treatment improved seedling emergence of bluebunch wheatgrass but did not improve crested wheatgrass emergence. Dissimilarity between species in their response to SSC may be associated with differences in moisture requirements and germination velocity. Crested wheatgrass is a favored species for establishment on harsh rangeland sites because of its ability to germinate rapidly (e.g., Rawlins 2009), even under intermittent drought conditions (Wilson 1973). In this experiment, where moisture availability was highest at the beginning of the experiment, species with faster germination and emergence times would be favored. Potentially, the germination requirements for crested wheatgrass were met in the control treatment, whereas those for bluebunch wheatgrass were not. Thus, for crested wheatgrass, the hydrologic benefits secured by SSC were not needed, whereas, for bluebunch wheatgrass, those same benefits were essential. These results may indicate that SSC may extend the window where seedling emergence is possible.

Soil-water repellency decreases the efficiency of rainfall or irrigation by reducing the soil's ability to absorb and retain water (Ritsema et al. 2008). Based on results from experiment 1 , we assume that survival in the seed-coating treatment was enhanced because of the surfactant reversing the effects of soilwater repellency by decreasing runoff and increasing percolation and water retention. These effects would increase soil water availability throughout the evaluation period by enhancing the amount of water moving through the soil rather than over it. In this study, it appears that the application of surfactants through seed-coating technology helped to restore hydrologic function, thereby, enhancing plant survival and growth.

SSC technology may have particular utility in arid, lowelevation sites where the probability of successful postfire reseedings can be low (Call and Roundy 1991; Lysne and Pellant 2004; James and Svejcar 2010). In these systems, small increases in survival can equate to a significant improvement in restoration success. SSC technology may find its greatest value in improving establishment success of native plant materials, which are often more costly, limited in availability (Roundy et al. 1997), and, in some cases, experience lower establishment success than their introduced counterparts (Shaw et al. 2005; James and Svejcar 2010). In this scenario, effective seed-coating treatments could directly lower restoration costs by decreasing the amount of seed required to restore a site.

\section{IMPLICATIONS}

Large-scale catastrophic wildfires can have long-term environmental consequences by promoting soil erosion, air pollution, and weed infestation. Consequently, implementation of successful restoration practices after a catastrophic wildfire can be critical for long-term ecosystem health. The results of this study indicate that SSC technology may mitigate these effects by improving soil hydrologic function and increasing establishment of desired species. By enhancing infiltration, SSCs may have the capacity to directly minimize runoff and erosion after 
a fire. Long-term positive effects may be realized through SSC's ability to improve seedling emergence and survival and, thus, indirectly increase site stability and decrease weed invasion.

Because of a lack of correlation between greenhouse and field settings, the results of this study need to be interpreted with caution. Future research is needed to confirm these findings in the field, before SSC technology is recommended as a postfire restoration treatment.

\section{ACKNOWLEDGMENTS}

We are grateful to Steven Petersen (Brigham Young University) and Alan Taylor (Cornell University) for their assistance in the initial development of this technology, and to Stu Barclay (Summit Seed Coatings) for his instruction on standard seed coating methods and materials. We are also grateful to Kristen Monday for her aid in conducting this research and to Chad Boyd, Jeremy James, and Irene Karas for reviewing earlier versions of this manuscript.

\section{LITERATURE CITED}

Adams, S., B. R. Strain, and M. S. Adams. 1970. Water-repellent soils, fire and annual plant cover in a desert scrub community of southeastern California. Ecology 51:696-700.

Bureau of Land Management. 1999. Out of ashes, an opportunity. Boise, ID, USA: Bureau of Land Management, National Office of Fire and Aviation. 28 p.

Cassel, D., and D. Nielsen. 1986. Field capacity and available water capacity. In: A. Klute [ED.]. Methods of soil analysis, part 1. 2nd ed. Madison, WI, USA: Soil Science Society of America. p. 901-926.

Call, C. S., and B. A. Roundy. 1991. Perspectives and processes in revegetation of arid and semiarid rangelands. Journal of Range Management 44:543-549.

DeBano, L. F., and C. E. Conrad. 1974. Effect of a wetting agent and nitrogen fertilizer on establishment of ryegrass and mustard on a burned watershed. Journal of Range Management 27:57-60.

DeBano, L. F., S. M. Savage, and D. A. Hamilton. 1976. The transfer of heat and hydrophobic substances during burning. Soil Science Society of America Proceedings 40:779-782.

DeBano, L. F., L. D. Mann, and D. A. Hamilton. 1970. Translocation of hydrophobic substances into soil by burning organic litter. Soil Science Society of America Proceedings 34:130-133.

DeBano, L. F. 1981. Water repellent soils: a state-of-the-art. Berkley, CA, USA: USDA Forest Service. General Technical Report, PSW-46. 21 p.

DoerR, S. H., R. A. Shakesby, and L. H. MacDonald. 2009. Soil water repellency: A key factor in post-fire erosion. In: A. Cerda and P. Robichaud [EDs.]. Fire effects on soils and restoration strategies. Enfield, NH, USA: Science Publishers, Inc. p. 197-224.

DoerR, S. H., R. A. Shakesby, and R. P. D. Walsh. 2000. Soil water repellency, its characteristics, causes, and hydro-geomorphological consequences. Earth Science Reviews 51:33-65.

Epanchin-Niell, R., J. Englin, and D. Nalle. 2009. Investing in rangeland restoration in the Arid West, USA: Countering the effects of an invasive weed on the longterm fire cycle. Journal of Environmental Management 91:370-379.

Hardegree, S. P., T. A. Jones, B. A. Roundy, N. L. Shaw, and T. A. Monaco. 2011. Assessment of range planting as a conservation practice [chapter 4]. In: D. D. Briske [ED.]. Conservation benefits of rangeland practices: assessment, recommendations, and knowledge gaps. Lawrence, KS, USA: USDA-NRCS. p. $171-212$.

JAMES, J. J., AND T. J. SVEJCAR. 2010. Limitations to postfire seedling establishment: the role of seeding technology, water availability, and invasive plant abundance. Rangeland Ecology \& Management 63:91-495.

JAmes, J. J., T. J. SveJCAR, And M. J. RinelLA. 2011. Demographic processes limiting seedling recruitment in aridland restoration. Journal of Applied Ecology 48:961-969.
KaRnoK, K. J., AND K. A. TuCKer. 2001. Wetting agent treated hydrophobic soil and its effect on color, quality and root growth of creeping bentgrass. International Turfgrass Society Research Journal 9:537-541.

Kelling, K. A., P. E. Speth, F. J. Arriaga, and B. Lowery. 2003. Use of a nonionic surfactant to improve nitrogen use efficiency of potato. Acta Horticulturae 619:225-232.

KostKA, S. J. 2000. Amelioration of water repellency in highly managed soils and the enhancement of turfgrass performance through the systematic application of surfactants. Journal of Hydrology 231-232:359-368.

KosTKA, S. J. 2009. Systemic mitigation of environmental stress on plants and the fruit thereof. Cherry Hill, NJ, USA: US Patent and Trademark Office. US Patent Appl. No. 20090280985.

KostKa, S. J., and P. T. Bially. 2005. Synergistic surfactant interactions for enhancement of hydrophilicity in water repellent soils. International Turfgrass Society Research Journal 10:108-114.

Kostka, S. J., G. Schuermann, and M. FrankLin. 2008. Alkyl-capped block copolymer surfactants for remediation of soil water repellency and heterogeneous rootzone moisture. In: C. Martin, G. Linder, and A. Rohde [EDS.]. Pesticide formulations and delivery systems, 27th volume: traditional and nontraditional developments. West Conshohocken, PA, USA: ASTM. p. 69-76.

Krammes, J. S., AND J. OsBorn. 1969. Water-repellent soils and wetting agents as factors influencing erosion. In: L. F. DeBano and J. Letey [EDS.]. Proceedings of a symposium on water repellent soils; May 1968; Riverside, CA, USA. Riverside, CA, USA: University of California Riverside. 187 p.

Lysne, C., And M. Pellant. 2004. Establishment of aerially seeded big sagebrush following southern Idaho wildfires. Boise, ID, USA: US Department of the Interior, Bureau of Land Management, Idaho State Office. Technical Bulletin 2004-01. 14 p.

MacDonald, L. H., and I. J. Larsen. 2009. Effects of forest fires and post-fire rehabilitation: a Colorado, USA case study. In: A. Cerdá and P. R. Robichaud [EDS.]. Fire effects on soils and restoration strategies. Enfield, NH, USA: Science Publishers, Inc. p. 423-452.

Madsen, M. D., S. L. Petersen, B. A. Roundy, A. G. Taylor, and B. G. Hopkins. 2012. Comparison of postfire soil water repellency amelioration strategies on bluebunch wheatgrass and cheatgrass survival. Rangeland Ecology \& Management 65:182-188.

Madsen, M. D., S. L. Petersen, and A. G. Taylor. 2010. Seed coating compositions and methods for applying soil surfactants to water-repellent soil. Geneva, Switzerland: World Intellectual Property Organization. Publication No. WO/ 2010/111309. International Application No. PCT/US2010/28371.

Madsen, M. D., D. L. Zvirzdin, S. L. Petersen, B. A. Roundy, B. G. Hopkins, and D. G. ChandLer. 2011. Soil water repellency within a burned piñon-juniper woodland: spatial distribution, severity, and ecohydrologic implications. Soil Science Society of America Journal 75:1543-1553.

Mitra, S., E. Vis, R. Kumar, R. Plumb, And M. Fam. 2006. Wetting agents and cultural practices increase infiltration and reduce runoff losses of irrigation water. Biologia, Bratislava 61(Suppl 19):S353-S357.

Moore, D., S. J. Kostka, T. J. Boerth, M. Franklin, C. J. Ritsema, L. W. Dekker, K. Oostindie, C. Stoof, and J. Wesseling. 2010. The effect of soil surfactants on soil hydrological behavior, plant growth environment, irrigation efficiency, and water conservation. Journal of Hydrology and Hydromechanics 58:142-148.

Osborn, J., J. Letey, L. F. DeBano, and E. Terry. 1967. Seed germination and establishment as affected by non-wettable soils and wetting agents. Ecology 48:494-497.

Oostindie, K., L. W. Dekker, J. G. Wesseling, and C. J. Ritsema. 2011. Improvement of water movement in an undulating sandy soil prone to water repellency. Vadose Zone Journal 10:262-269.

Osborn, J., J. Letey, L. F. DeBano, and E. Terry. 1967. Seed germination and establishment as affected by non-wettable soils and wetting agents. Ecology 48:494-497.

Pelishek, R. E., J. Osborn, and J. Letey. 1962. The effect of wetting agents on infiltration. Soil Science Society of America Proceedings 26:595-598.

Peppin, D. L., P. Z. Fulé, C. H. Sieg, J. L. Beyers, and M. E. Hunter. 2010. Postwildfire seeding in forests of the west: trends, costs, effectiveness, and use of native seed. Final report to the Joint Fire Sciences Program (JFSP). Boise, ID, USA: JFSP, National Interagency Fire Center. Project ID 08-2-1-11. 61 p. 
PRism Climate Group, Oregon State University. 2011. Parameter-elevation regressions on independent slopes model climate mapping system data set. Available at: http://www.prismclimate.org. Accessed 6 March, 2011.

Ravi, S., P. D. Odorico, T. Huxman, and S. L. Coluins. 2010. Interactions between soil erosion processes \& fires: Implications for the dynamics of fertility islands. Rangeland Ecology \& Management 63:267-274.

RAWLINS, J. K. 2009. Wet thermal accumulation modeling of germination of western US rangeland species [thesis]. Provo, UT, USA: Brigham Young University. $49 \mathrm{p}$.

Richards, R. T., J. C. Chambers, and C. Ross. 1998. Use of native plants on federal lands: policy and practice. Journal of Range Management 51:625-632.

Ritsema, C. J., L. W. Dekker, K. Oostindie, D. Moore, and B. Leinauer. 2008. Soil water repellency and critical soil water content. chapter in soil science: step-by-step field analysis. Madison, WI, USA: Soil Science Society of America. p. 97-112.

Robichaud, P. R., J. L. Beyers, and D. G. Neary. 2000. Evaluating the effectiveness of post-fire rehabilitation treatments. Fort Collins, C0, USA: USDA Forest Service Rocky Mountain Research Station. General Technical Report RMRS-GTR-63. 85 p.

Robichaud, P. R., T. R. Lillybridge, and J. W. Wagenbrenner. 2006. Effects of postfire seeding and fertilization on hillslope erosion in north-central Washington, USA. Catena 67:56-67.
Roundy, B. A., N. L. Shaw, D. T. Bоотн. 1997. Using native seeds on rangelands. In: N. L. Shaw, And B. A. Roundy [comps.]. Proceedings-using seeds of native species on rangelands; 16-21 February 1997; Rapid City, SD, USA. Ogden, UT, USA: USDA Forest Service Rocky Mountain Research Station. General Technical Report INT-GTR-372. p. 1-8.

Savage, S. M. 1974. Mechanism of fire-induced water repellency in soils. Soil Science Society of America Proceedings 38:652-657.

Shaw, N. L., A. M. DeBolt, R. Rosentreter. 2005. Reseeding big sagebrush: techniques and issues. In: N. Shaw, M. Pellant, AND S. B. Monsen [Comps.]. Sage-grouse habitat restoration symposium proceedings; 4-7 June 2001; Boise, ID, USA. Fort Collins, C0, USA: USDA Forest Service Rocky Mountain Research Station. Proc. RMRS-P-38. p. 99-108.

Soldat, D. J., B. Lowery, AND W. R. Kussow. 2010. Surfactants increase uniformity of soil water content and reduce water repellency on sand-based golf putting greens. Soil Science 175:111-117.

Valoras, N., J. F. Osborn, And J. Letey. 1974. Wetting agents for erosion control on burned watersheds. California Agriculture 28:12-13.

WILSON, A. M. 1973. Responses of crested wheatgrass seeds to environment. Journal of Range Management 26:43-46. 